\title{
Habitat characteristics and life history explain reproductive seasonality in lagomorphs
}

\author{
Sandra A. Heldstab ${ }^{1,2}$ (1) \\ Received: 12 January 2021 / Accepted: 16 April 2021 / Published online: 30 April 2021 \\ (c) The Author(s) 2021
}

\begin{abstract}
Lagomorphs show extensive seasonal variation in their reproduction. However, the factors causing this large variation have so far mostly been investigated intraspecifically and therefore provide only some exemplary comparisons of lagomorph reproductive seasonality. The present study applies both a categorical description (birth season categories 1-5) and a quantitative measure (birth season length in months) to summarize the degree of birth seasonality in the wild of 69 lagomorph species. Using a comparative approach, I tested the influence of 13 factors, comprising six habitat, five life history and two allometric variables on birth season length in lagomorphs. Leporids mainly show non-seasonal birthing patterns with high intraspecific variation. Their opportunistic breeding strategy with high reproductive output and their large distribution areas across wide latitude and elevation ranges might be the reasons for this finding. Ochotonids reproduce strictly seasonally, likely because they live at northern latitudes, are high-altitude specialists, and occur in limited distribution areas. The most important factors associated with variation in lagomorph birth seasonality are mid-latitude, mean annual temperature and precipitation of a species' geographical range and life history adaptations including fewer but larger litters in seasonal habitats. Birth seasons become shorter with increasing latitude, colder temperatures, and less precipitation, corresponding to the decreasing length of optimal environmental conditions. Leporid species with shorter breeding seasons force maternal resources into few large litters to maximise reproductive output while circumstances are favourable. Since allometric variables were only weakly associated with reproductive seasonality, life history adaptations and habitat characteristics determine birth seasonality in Lagomorpha.
\end{abstract}

Keywords Lagomorpha $\cdot$ Reproduction $\cdot$ Latitude $\cdot$ Temperature $\cdot$ Litter size $\cdot$ Gestation length

\section{Introduction}

Reproduction is energetically very expensive for most organisms. This is particularly true for placental mammals, where females bear the metabolic costs of pregnancy and lactation (McNab 2006; Speakman 2008; Heldstab et al. 2017). For mammals living in seasonal habitats with frequent periods of food scarcity, it is therefore essential that birth and lactation

Handling Editor: Stéphanie Schai-Braun.

Sandra A. Heldstab

sandra.heldstab@uzh.ch

1 Department of Anthropology, University of Zurich, Winterthurerstrasse 190, 8057 Zurich, Switzerland

2 Clinic for Zoo Animals, Exotic Pets and Wildlife, Vetsuisse Faculty, University of Zurich, Winterthurerstrasse 260, 8057 Zurich, Switzerland occur during the most favourable time of the year to increase their reproductive success (e.g., Lancaster and Lee 1965; Soto et al. 2004).

Lagomorphs show extensive seasonal variation in their reproduction. In some species, such as many pikas (Ochotonidae), all breeding activity takes place during a very restricted part of the year of only around one to two months (e.g., Chapman and Flux 1990; Smith et al. 2018). Other lagomorph species are capable of reproducing during a broader time window (e.g., Barkalow 1962; Newson 1964; Franken and Hik 2004; Rioja et al. 2011) or throughout the year but show seasonal birth peaks (e.g., Prakash and Taneja 1969; Stubbe et al. 1991; Vázquez et al. 2007). Lastly, in a fourth group of species, reproduction is entirely non-seasonal (Hayssen et al. 1993; Wilson et al. 2016).

Several ecological, physiological, and social factors have been proposed to explain this broad spectrum of reproductive seasonality in Lagomorpha (e.g., Barkalow 1962; 
Conaway et al. 1974; Swihart 1984; Boyd 1985; Ben Saad and Maurel 2002; Alves and Rocha 2003; Franken and Hik 2004; Portales et al. 2004; Rödel et al. 2005; Virgos et al. 2006; Tablado et al. 2009; Rioja et al. 2011; Schai-Braun et al. 2017). However, this knowledge derives almost exclusively from single-species studies and therefore provides only some exemplary comparisons of seasonality in reproduction between different lagomorph species. Furthermore, future studies enhancing our understanding of reproductive behaviour in the order Lagomorpha, with approximately one-fifth of species being threatened with extinction (Smith 2018), are also fundamental to captive-breeding programs and conservation management (Côté 2003). The importance of lagomorphs both as a pest of agricultural significance and as a key prey species and major human food resource additionally emphasizes the need to understand what controls their reproductive activity (Cowan and Bell 1986; Tablado et al. 2009; Delibes-Mateos et al. 2011; Lumpkin and Seidensticker 2011; Smith et al. 2019).

The first aim of this paper is therefore to collate and summarize data on birth seasonality from the wild of the majority of lagomorph species and compare them interspecifically. The second objective is to assess the influence of 13 factors on reproductive seasonality in lagomorphs that have been suggested in previous studies to play a role in birth seasonality: namely, six habitat characteristics (mid-latitude and latitude range of a species' geographical distribution (Sadleir 1969; Conaway et al. 1974; Bronson 1988), altitude (Conaway et al. 1974; Schai-Braun et al. 2017), temperature (Portales et al. 2004; Rödel et al. 2005; Vázquez et al. 2007; Tablado et al. 2009; Portales-Betancourt et al. 2012; Wells et al. 2016), precipitation (Wood 1980; Franken and Hik 2004; Portales et al. 2004; Vázquez et al. 2007; Rioja et al. 2011; Portales-Betancourt et al. 2012), and home range size (Innes and Millar 1995; Spady et al. 2007)), two allometric variables (sexual size dimorphism (Valdespino 2007; Zerbe et al. 2012; Heldstab 2021) and body mass (Janson and Verdolin 2005; Rödel et al. 2005; Tökölyi et al. 2014)), and five life history traits (litter size, litters per year, gestation length, weaning age, and age at sexual maturity (Lord 1960; Conaway et al. 1974; Chapman 1984; Swihart 1984; Bronson 1989; Tablado et al. 2009; Tökölyi et al. 2014)). The influence of these 13 factors on birth seasonality will be tested across the whole order Lagomorpha and for each of the distinct four ecotypes (hares and jackrabbits, rabbits, rock- and talus-dwelling pikas, and burrowing pikas) separately. For a more detailed description of how these factors may influence birth seasonality, see Heldstab (2021) and supplementary material of Heldstab et al. (2018).

Lastly, the third aim is to compare reproductive seasonality of Lagomorpha with other mammalian orders. Relative to most other mammals, lagomorphs are characterised by extremely rapid foetal and neonatal growth rates (Case
1978; Eisenberg 1981; Swihart 1984) including post-partum oestrus (females can simultaneously suckle one litter while carrying another in the uterus) and superfetation in the genus Lepus (female hares are able to carry a second fertilized ovum in their uterus already containing a pregnancy) (Flux 1967). These characteristics allow lagomorphs to accomplish a reproductive cycle and maximize litter production within a very short time period but impose high energetic demands on females (Flux 1981; Keith 1981; Swihart 1984). Lagomorph species are therefore expected to breed only during optimal environmental conditions in seasonal habitats resulting in a pronounced birth season for species living at high latitudes and/or elevations. On the other hand, the fast reproductive cycle allows lagomorph species to breed opportunistically, e.g., responding to a sudden increase in food availability after rainfall, which may result in a non-seasonal birthing pattern with high intraspecific variation for those species living in regions with large variations in temperature and/or precipitation.

\section{Materials and methods}

To investigate which factors influence reproductive seasonality in the natural habitat of different lagomorphs, a broad dataset on birth seasonality covering 69 species was compiled from the literature. Birth seasonality was described both in a quantitative and a categorical way (Table 1). As a continuous measure, birth season length in months was used as in Heldstab (2021). For the categorical measure, each species was assigned to one of five birth seasonality categories based on its birthing pattern following (Zerbe et al. 2012; Heldstab et al. 2018, 2021; Heldstab 2021): Category 1: narrow peak (less than approximately 60 days), no births for the rest of the year; category 2: expanded peak ( $>60$ days) or double peak, no births for the rest of the year; category 3 : peak(s) accompanied by a small number of births throughout the year; category 4: births throughout the year, undulating pattern (preferred seasons possible). category 5: constant births throughout the year without a clear preferred season. If several sources of data were available for one species, preference was given to the study with the highest number of births, the longest study period or the birth season most often mentioned in the literature.

Data on all explanatory variables, namely, the habitat characteristics (mid-altitude, latitude range, mean altitude, mean annual temperature and precipitation of the species' geographical distribution, and home range size), allometric variables (adult body mass and sexual size dimorphism expressed as the ratio of male vs. female body mass), and life-history traits (gestation length, litters per year, litter size, weaning age, and age at sexual maturity) were compiled from the published literature. Although litter size is a 


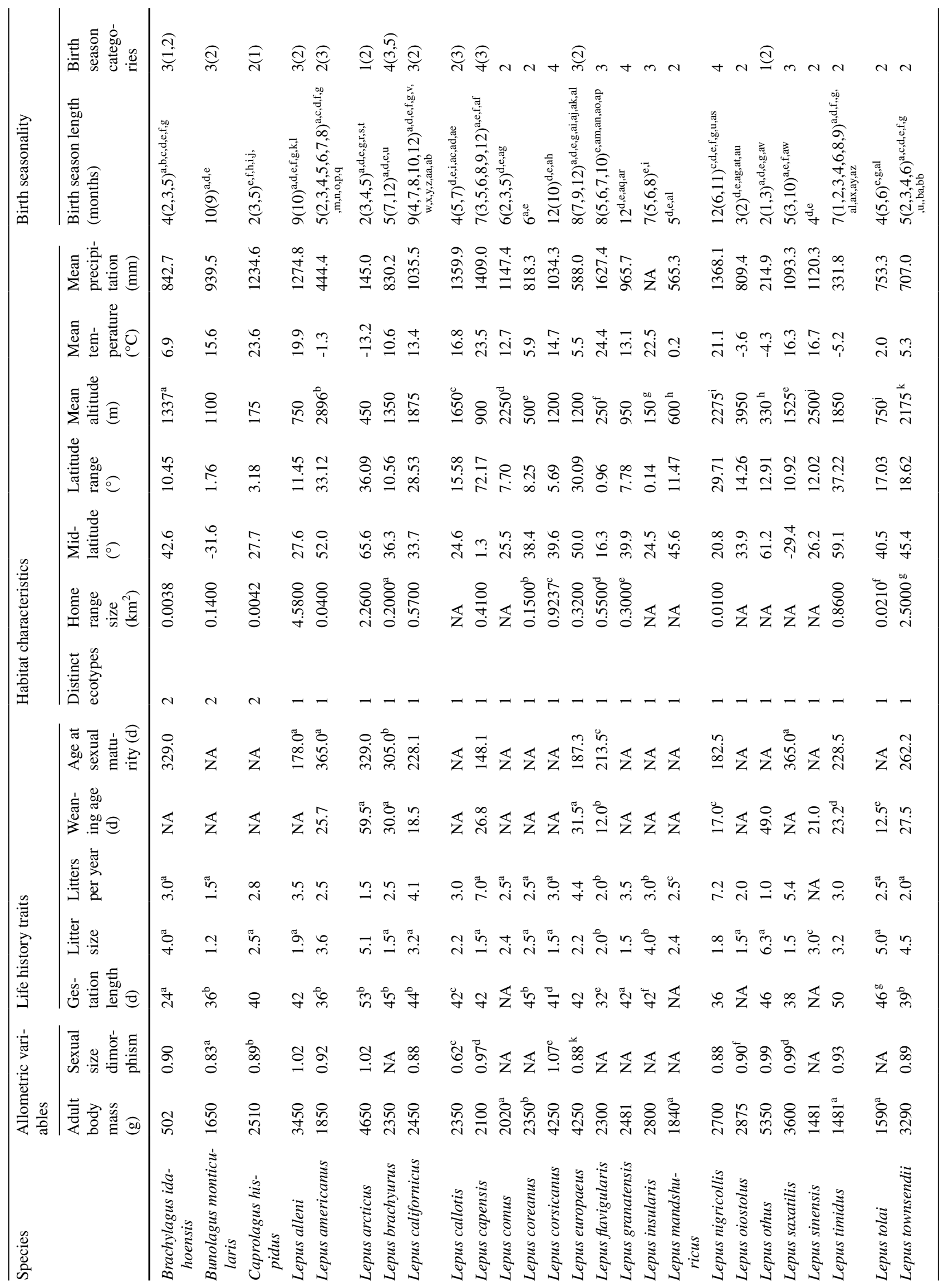




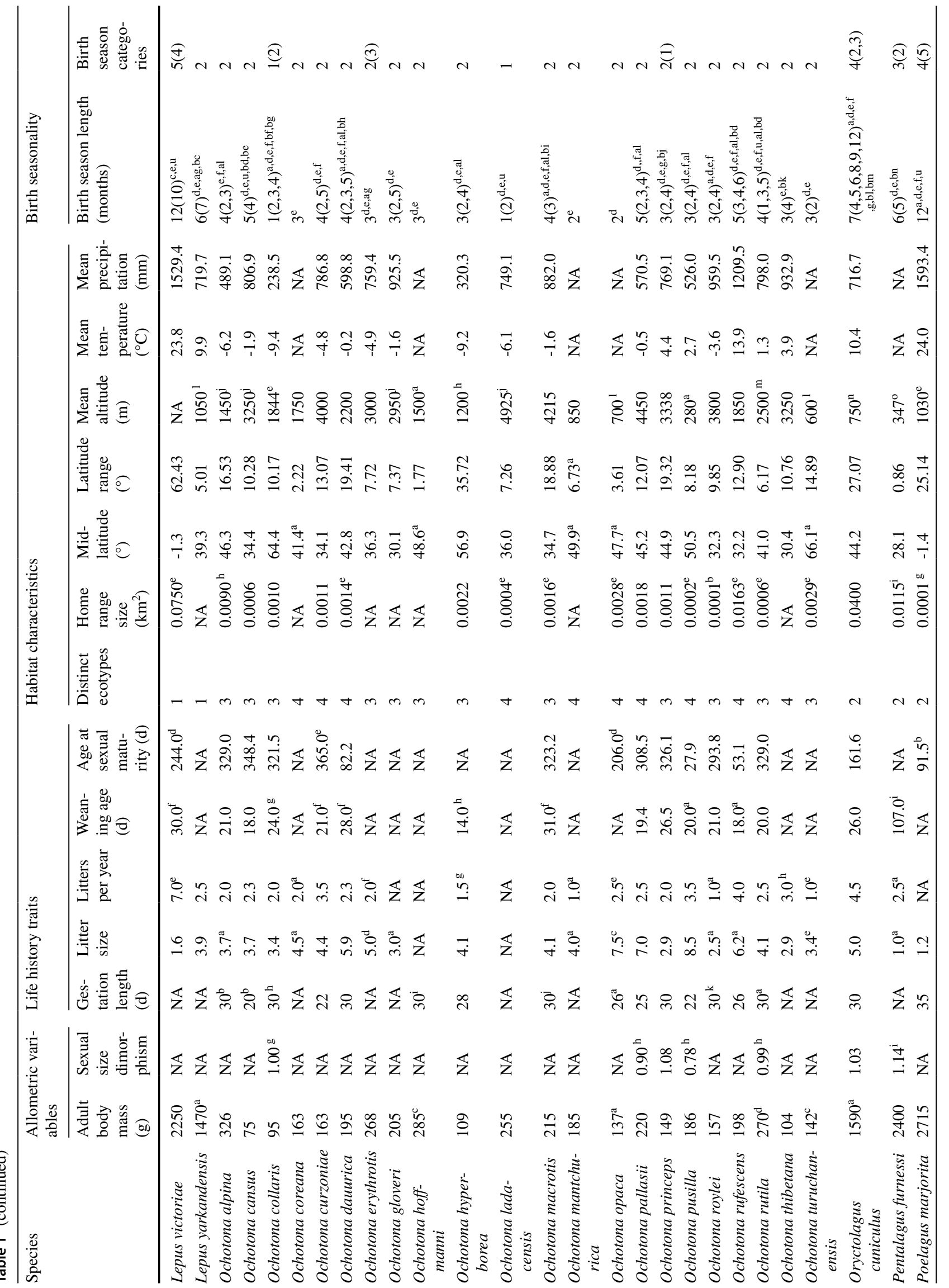




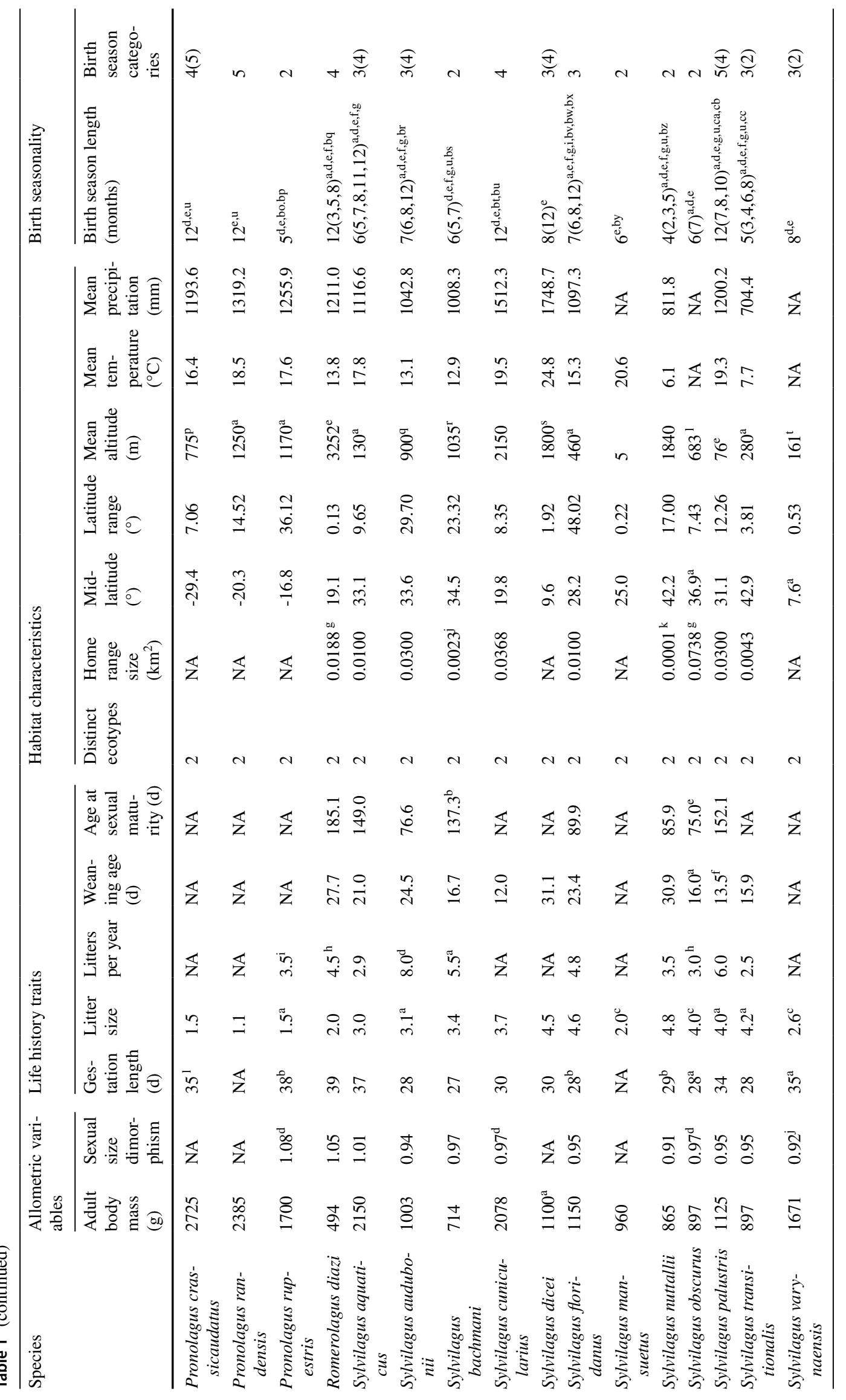




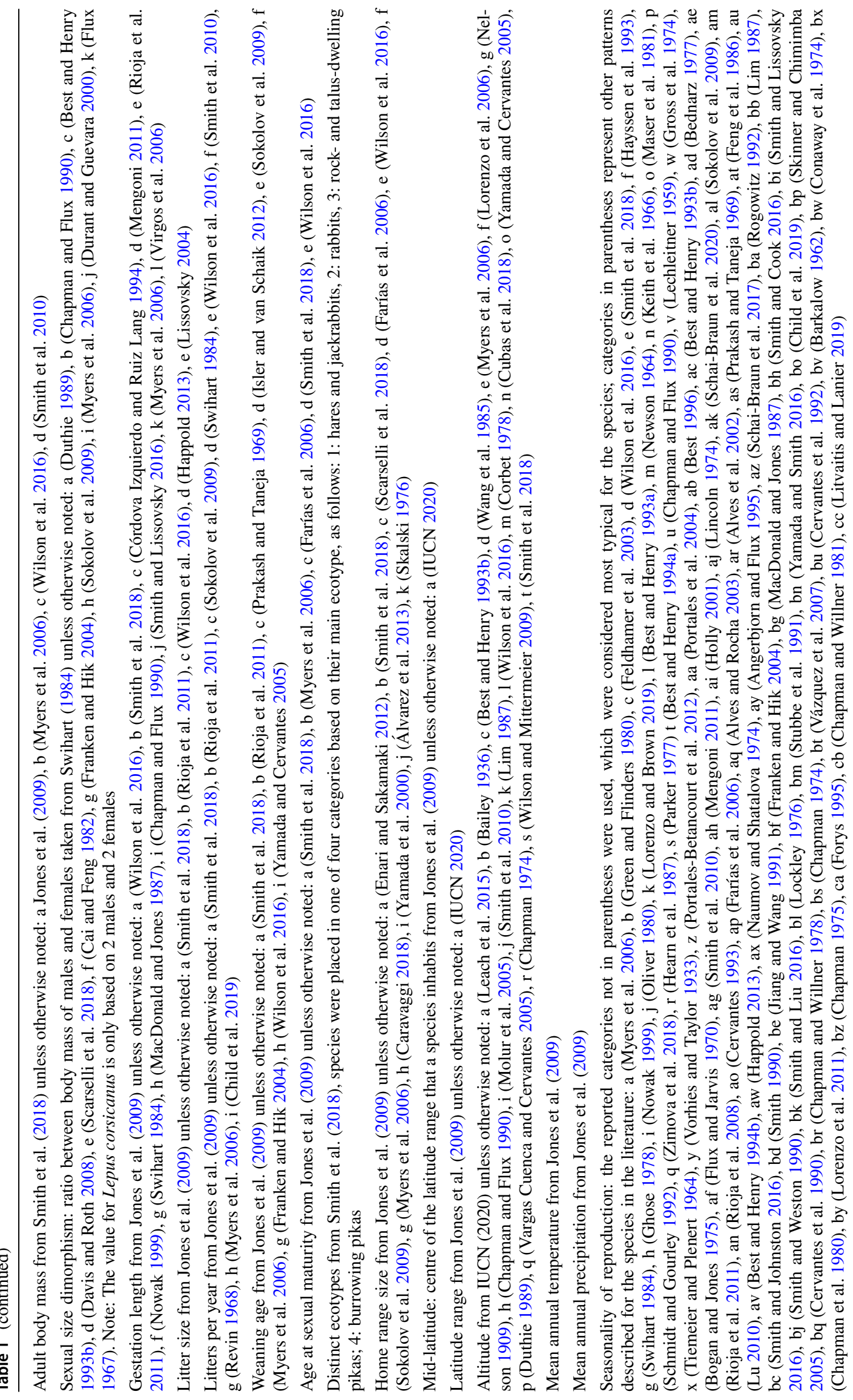


(a)

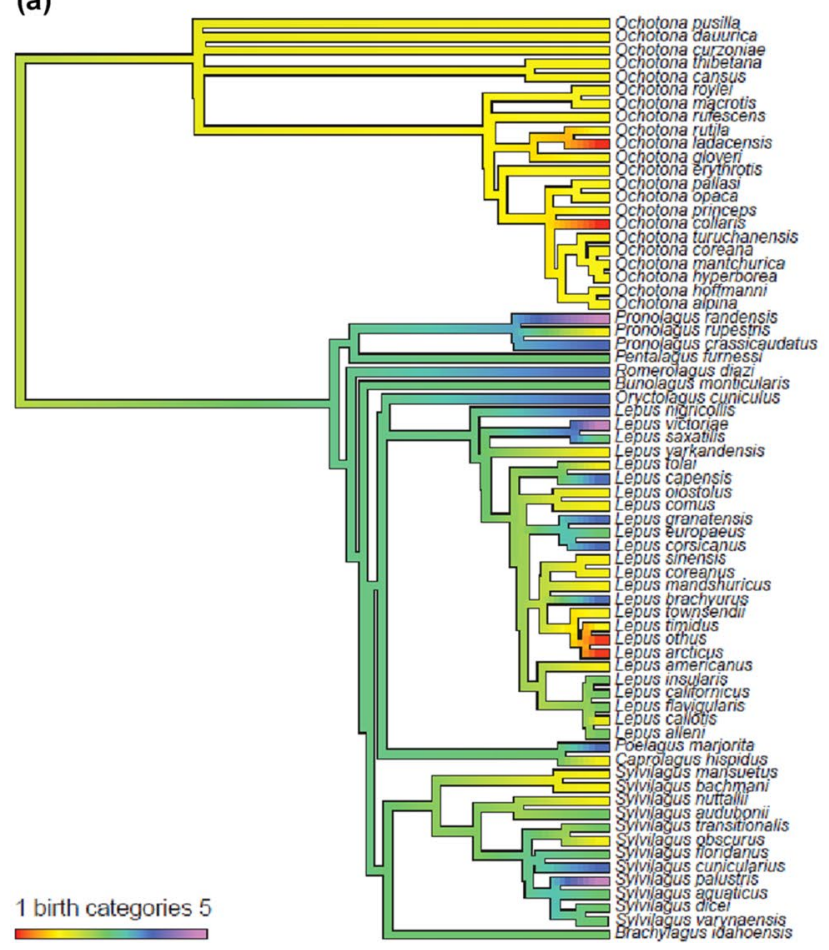

Fig. 1 The phylogenetic tree used in the present study from Fritz et al. (2009), with an indication how a the birth season categories and $\mathbf{b}$ the birth season length in months are distributed across the

standard measure, it is unfortunately rarely clearly defined in the literature as either number of embryos conceived, number of healthy embryos close to parturition (after accounting for the resorption of embryos) or the number of young at parturition. Furthermore, the number and size of litters have been shown to vary intraspecifically within lagomorphs according to latitude, elevation, snowmelt, the probability of survival of young, and due to metapopulation dynamics (e.g., Keith et al. 1966; Millar 1973; Conaway et al. 1974; Hewson and Taylor 1975; Smith 1978; Tablado et al. 2009). In the present study, preference was given to litter size values deriving from the number of young at parturition and litter size and litters per year values most commonly mentioned in the literature. Detailed sources of data for the whole dataset are given in Table 1.

Statistical analyses were performed in JMPTM 13.0 (SAS Institute Inc 1989-2016) and in R 4.0.4 (R Core Team 2021). All analyses were controlled for phylogenetic non-independence using phylogenetic generalized least-squares regressions (PGLS: Martins and Hansen 1997) using the "caper" package (Orme et al. 2013) in R. PGLS is a modification of generalised least squares using the knowledge of phylogenetic relationships to produce an estimate of expected covariance in cross-species data (Symonds and Blomberg 2014). Closely related species are assumed to have more similar (b)

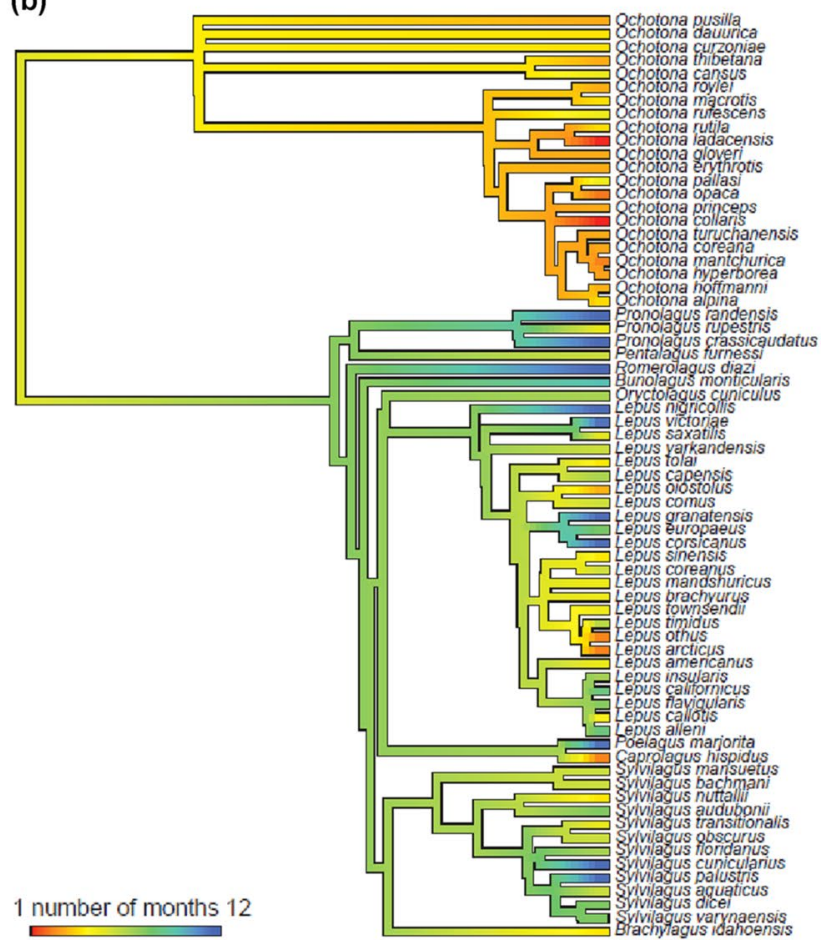

tree, ranging from very short (a highly seasonal reproductive pattern, red) to very long (a non-seasonal reproductive pattern, dark blue)

traits because of their shared ancestry and hence produce more similar residuals from the least-squares regression line. By taking into account the expected covariance structure of these residuals, modified slope and intercept estimates are generated that can account for interspecific autocorrelation due to phylogeny. Caper estimates PGLS model parameters in maximum likelihood (Orme et al. 2013) and the parameter lambda $(\lambda)$, which quantifies the magnitude of the phylogenetic signal in the model residuals (Freckleton et al. 2002). The value of $\lambda$ can vary between 0 , indicating no phylogenetic signal, and 1, indicating that the observed pattern fits a Brownian motion model of trait evolution along the branches of the phylogeny such that similarity between species is directly proportional to relatedness.

The lagomorph phylogeny was extracted from the composite mammalian supertree including branch length estimations provided by Fritz et al. (2009) and is given in Fig. 1. Seven species (Lepus victoriae, Ochotona coreana, Ochotona hoffmanni, Ochotona mantchurica, Ochotona opaca, Sylvilagus obscurus, and Sylvilagus varynaensis) were not part of this supertree and therefore added manually in Mesquite (Maddison and Maddison 2001) following the latest IUCN taxonomy (IUCN 2020).

To determine the most important explanatory variables of birth seasonality either measured in categories or number of 
Fig. 2 The distribution of lagomorph species according to their reproductive seasonality characterized by a the birth season categories and $\mathbf{b}$ the birth season length in months
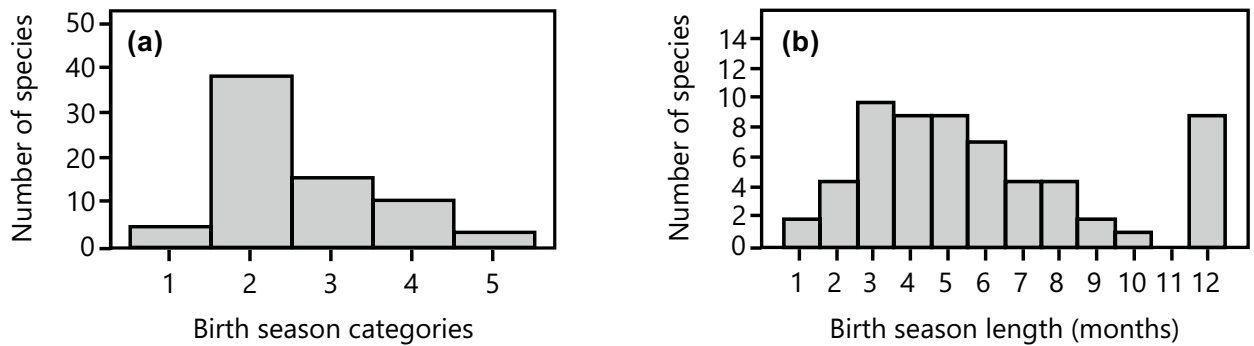

months, all thirteen explanatory variables mentioned above were tested in univariate PGLS analyses. Unfortunately, performing multivariate regressions or multi-model averaging was impossible because each explanatory variable had a different sample size (due to missing values for several understudied species) and there was problematic high multicollinearity between predictors (Rogerson 2001) (Online Resource 1). The critical level of significance $(P=0.050)$ was adjusted by Bonferroni correction for multiple testing to $(P=0.004)$. Model assumptions of normality and homogeneity of residuals were checked by visually inspecting histograms and qq-plots of the residuals as well as by plotting residuals against fitted values. The values of home range size, adult body mass, gestation length, weaning age, and age at sexual maturity were log-transformed before analysis to reduce the skew of their distribution. Additionally, to investigate the effect of habitat characteristics, allometric variables and life-history traits on birth seasonality in more detail, the four distinct ecotypes of lagomorphs (hares and jackrabbits, rabbits, rock- and talus-dwelling pikas, and burrowing pikas) were each analysed separately.

\section{Results}

A significant positive correlation between the five ordinal birth season categories and the continuous variable, the birth season length in months, was found (PGLS: $p<0.001$, $n=69, \lambda<0.001, \beta=1.055, \mathrm{SE}=0.019, t=14.000)$, indicating that the quantitative and the categorical approach yielded a comparable ranking of species. The ordinal birth seasonality categories showed a right-skewed distribution with the highest number of species in category 2 , indicating that the majority of lagomorphs reproduce during an expanded but determined time window of more than 2 months with no births for the rest of the year (Fig. 2a). The birth season length in months ranged from 1 to 12 months and its distribution was also right skewed but showed a second peak at birth season length of 12 months with $14.5 \%$ of species reproducing year-round (Fig. 2b). Lagomorphs show a high degree of intraspecific variation in birth season length. As evident in Table 1, for many species, various birth season lengths have been described in the literature ranging in the most extreme cases of volcano rabbits (Romerolagus diazi) and cape hares (Lepus capensis) from 3 to 12 months and of mountain hares (Lepus timidus) from 1 to 9 months.

The phylogenetic patterns of reproductive seasonality are given in Fig. 1a and b. The most strictly seasonally reproducing group were the pikas (Ochotonidae) with an average birth season length of 3.23 months and the most seasonal species, the collared pika (Ochotona collaris) and the Ladak pika (Ochotona ladacensis) followed by hares with an average birth season length of 6.60 months, and the rabbits with an average birth season length of 7.73 months.

The most important factors influencing the degree of birth seasonality in lagomorphs were mid-latitude, mean annual temperature and precipitation of a species' geographical distribution, litter size, and litters per year (Tables 2 and 3). Birth seasonality either measured in months or categories was negatively correlated to the mid-latitude of a species' geographical distribution (Fig. 3a and b) showing that reproductive periods became shorter with increasing latitude. Mean annual temperature (Fig. 3c and d) and precipitation (Fig. 3e and f) were positively correlated with reproductive seasonality, indicating that lagomorph species living in warmer habitats with more precipitation exhibit an expanded birth season. Litters per year was positively (Fig. 3g and h) and litter size negatively (Fig. $3 \mathrm{i}$ and j) correlated with birth season length, suggesting that species with a more pronounced birth seasonality have larger but fewer litters per year than species which have a more expanded birthing pattern. Adult body mass was positively linked to birth seasonality but only if measured in months (Fig. 3k and 1), where heavier species are less likely to be seasonal breeders. Latitude range, mean altitude of a species' geographical distribution, home range size, gestation length, weaning age, age at sexual maturity, and sexual size dimorphism had no influence on reproductive seasonality in lagomorphs (Tables 2 and 3).

Investigating each of the four distinct ecotypes separately, I found that for hares and jackrabbits, the most important factors influencing birth seasonality were litter size, litters per year and mean annual temperature (Online Resources 2 and 3). Mean annual temperature and litters per year were positively and litter size negatively correlated with birth seasonality either measured in the number of 
Table 2 Results from phylogenetic generalized least squares regression models testing for the effect of various predictor variables on birth season length in months
Table 3 Results from phylogenetic generalized least squares regression models testing for the effect of various predictor variables on reproductive seasonality characterized by five birth season categories

\begin{tabular}{lrrrrrrr}
\hline Predictor variables & Estimate & Std. error & $t$-value & $P$-value & $N$ & \multicolumn{1}{c}{$\lambda$} & Adj. $R^{2}$ \\
\hline Habitat characteristics & & & & & & & \\
Mid-latitude & $\mathbf{0 . 0 9 3}$ & $\mathbf{0 . 0 2 3}$ & $-\mathbf{4 . 1 0 4}$ & $<\mathbf{0 . 0 0 1}$ & $\mathbf{6 9}$ & $\mathbf{0 . 2 3 5}$ & $\mathbf{0 . 1 8 9}$ \\
Latitude range & 0.017 & 0.023 & 0.726 & 0.470 & 69 & 0.427 & -0.007 \\
Mean altitude & $<0.001$ & $<0.001$ & 0.328 & 0.744 & 68 & 0.457 & -0.014 \\
Mean annual temperature & $\mathbf{0 . 2 0 8}$ & $\mathbf{0 . 0 3 0}$ & $\mathbf{6 . 8 7 4}$ & $<\mathbf{0 . 0 0 1}$ & $\mathbf{6 1}$ & $\mathbf{0 . 0 0 0}$ & $\mathbf{0 . 4 3 5}$ \\
Mean annual precipitation & $\mathbf{0 . 0 0 5}$ & $<\mathbf{0 . 0 0 1}$ & $\mathbf{4 . 7 8 9}$ & $<\mathbf{0 . 0 0 1}$ & $\mathbf{5 9}$ & $\mathbf{0 . 1 6 0}$ & $\mathbf{0 . 2 7 4}$ \\
log(home range size) & 0.187 & 0.182 & 1.030 & 0.309 & 48 & 0.264 & 0.001 \\
Life history traits & & & & & & & \\
$\log$ (gestation length) & 0.238 & 2.469 & 0.096 & 0.924 & 53 & 0.295 & -0.019 \\
Litter size & $\mathbf{0 . 6 8 7}$ & $\mathbf{0 . 2 2 0}$ & $-\mathbf{3 . 1 1 9}$ & $\mathbf{0 . 0 0 3}$ & $\mathbf{6 7}$ & $\mathbf{0 . 2 5 2}$ & $\mathbf{0 . 1 1 7}$ \\
Litters per year & $\mathbf{1 . 0 8 0}$ & $\mathbf{0 . 2 1 1}$ & $\mathbf{5 . 1 1 7}$ & $<\mathbf{0 . 0 0 1}$ & $\mathbf{5 8}$ & $\mathbf{0 . 2 0 1}$ & $\mathbf{0 . 3 0 6}$ \\
log(weaning age) & -2.065 & 0.956 & -2.162 & 0.037 & 39 & 0.572 & 0.086 \\
$\log ($ age at sexual maturity) & -0.788 & 0.757 & -1.040 & 0.305 & 37 & 0.402 & 0.002 \\
Allometric variables & & & & & & & \\
log(mean adult body mass) & $\mathbf{1 . 3 7 2}$ & $\mathbf{0 . 2 7 1}$ & $\mathbf{5 . 0 6 7}$ & $<\mathbf{0 . 0 0 1}$ & $\mathbf{6 9}$ & $\mathbf{0 . 0 0 0}$ & $\mathbf{0 . 2 6 6}$ \\
Sexual size dimorphism & 5.479 & 4.175 & 0.753 & 0.457 & 36 & 0.219 & -0.013 \\
\hline
\end{tabular}

Significant effects after Bonferroni correction $(P=0.004)$ are highlighted in bold

\begin{tabular}{lrrrrrrr}
\hline Predictor variables & Estimate & Std. error & $t$-value & $P$-value & $N$ & $\lambda$ & Adj. $R^{2}$ \\
\hline Habitat characteristics & & & & & & & \\
Mid-latitude & $\mathbf{- 0 . 0 3 2}$ & $\mathbf{0 . 0 0 7}$ & $\mathbf{- 4 . 6 0 3}$ & $<\mathbf{0 . 0 0 1}$ & $\mathbf{6 9}$ & $\mathbf{0 . 1 6 1}$ & $\mathbf{0 . 2 2 9}$ \\
Latitude range & 0.010 & 0.007 & 1.365 & 0.177 & 69 & 0.505 & 0.013 \\
Mean altitude & $<0.001$ & $<0.001$ & -0.523 & 0.603 & 68 & 0.435 & -0.011 \\
Mean annual temperature & $\mathbf{0 . 0 6 5}$ & $\mathbf{0 . 0 0 9}$ & $\mathbf{7 . 0 6 8}$ & $<\mathbf{0 . 0 0 1}$ & $\mathbf{6 1}$ & $\mathbf{0 . 0 0 0}$ & $\mathbf{0 . 4 4 9}$ \\
Mean annual precipitation & $\mathbf{0 . 0 0 2}$ & $\mathbf{0 . 0 0 1}$ & $\mathbf{5 . 1 3 5}$ & $<\mathbf{0 . 0 0 1}$ & $\mathbf{5 9}$ & $\mathbf{0 . 1 2 1}$ & $\mathbf{0 . 3 0 4}$ \\
$\log ($ home range size) & 0.023 & 0.057 & 0.409 & 0.685 & 48 & 0.249 & -0.018 \\
Life history traits & & & & & & & \\
$\log ($ gestation length) & -0.255 & 0.733 & -0.348 & 0.729 & 53 & 0.301 & -0.017 \\
Litter size & $\mathbf{0 . 2 1 8}$ & $\mathbf{0 . 0 6 9}$ & $-\mathbf{3 . 1 5 7}$ & $\mathbf{0 . 0 0 2}$ & $\mathbf{6 7}$ & $\mathbf{0 . 2 7 7}$ & $\mathbf{0 . 1 2 0}$ \\
Litters per year & $\mathbf{0 . 4 2 3}$ & $\mathbf{0 . 0 5 9}$ & $\mathbf{7 . 1 4 1}$ & $<\mathbf{0 . 0 0 1}$ & $\mathbf{5 8}$ & $\mathbf{0 . 0 0 0}$ & $\mathbf{0 . 4 6 7}$ \\
$\log ($ weaning age) & -0.436 & 0.351 & -1.244 & 0.221 & 40 & 0.363 & 0.014 \\
$\log ($ age at sexual maturity) & -0.091 & 0.258 & -0.353 & 0.726 & 37 & 0.322 & -0.025 \\
Allometric variables & & & & & & & \\
$\log ($ mean adult body mass) & 0.263 & 0.174 & 1.511 & 0.136 & 69 & 0.305 & 0.019 \\
Sexual size dimorphism & 1.554 & 1.647 & 0.944 & 0.352 & 36 & 0.343 & -0.003 \\
\hline
\end{tabular}

Significant effects after Bonferroni correction $(P=0.004)$ are highlighted in bold months or categories. Additionally, mean annual precipitation showed a positive and mid-latitude negative relationship with reproductive seasonality in hares and jackrabbits but only if birth seasonality was measured in categories (Online Resources 2 and 3). For the other three ecotypes (rabbits, rock-and talus-dwelling pikas, and burrowing pikas), none of the 13 tested factors had a significant influence on birth seasonality after Bonferroni correction for multiple testing (Online Resources 4-9). The only factor close to significance was litters per year in rabbits showing a positive trend on birth season length measured in months (Online Resources 4).

\section{Discussion}

Lagomorphs occur worldwide (except in Antarctica) across a wide range of habitats spanning altitudes from sea level to more than $5000 \mathrm{~m}$ and latitudes from the equator up to $80^{\circ} \mathrm{N}$ (Wilson et al. 2016; Smith et al. 2018). Not surprisingly, lagomorphs are important for maintaining the equilibrium 
Fig. 3 Relationship between either the birth season length in months or the birth season categories and (a and b) the latitude of a species' geographical distribution, (c and d) mean annual temperature, (e and f) mean annual precipitation, (g and $\mathbf{h}$ ) litters per year, (i and $\mathbf{j}$ ) litter size, and ( $\mathbf{k}$ and $\mathbf{l})$ adult body mass. Body mass did not correlate with birth season categories. OLS regression lines (solid) and corresponding 95\% confidence intervals (grey shading) are shown. For statistics, see Tables 2 and 3
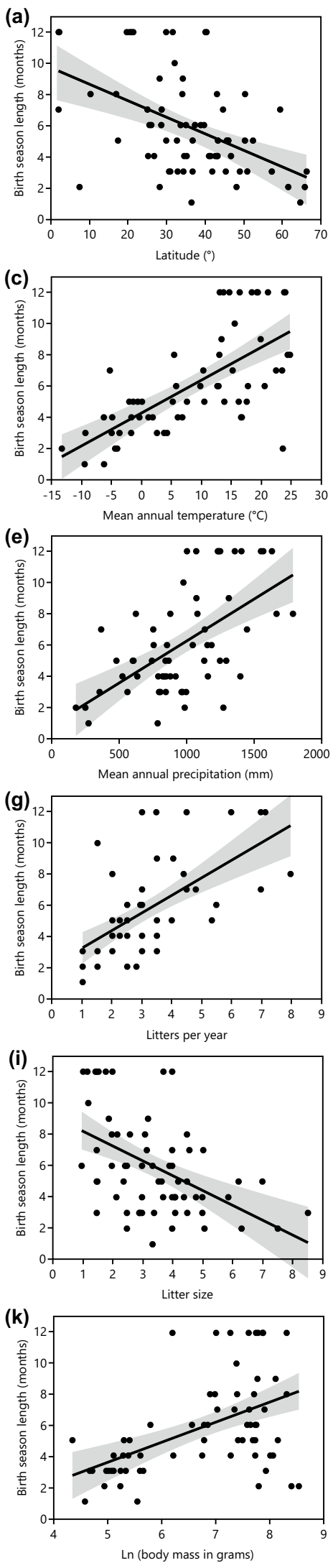
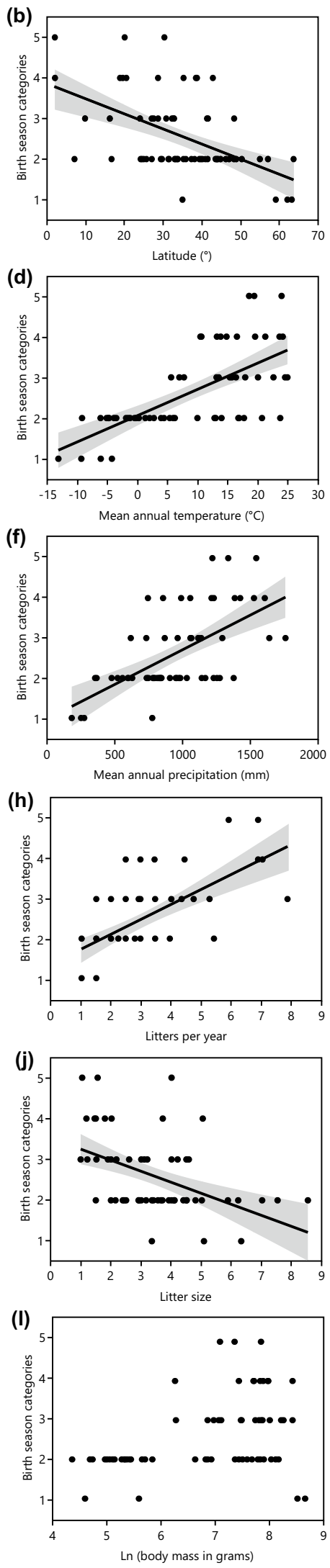
of many different ecosystems given that they are primary consumers and key prey species for a large array of predators (e.g., Tablado et al. 2009; Vaughan et al. 2013; Badingqiuying et al. 2016). This emphasizes the need to understand what controls population dynamics in Lagomorpha including their reproductive behaviour.

By applying both a categorical description (birth season categories 1-5) and a quantitative measure (birth season length in months), this study characterizes the degree of reproductive seasonality in the wild of 69 lagomorph species and tests the influence of 13 variables that were previously suggested to play a role in birth seasonality. I found that many lagomorph species exhibit a high degree of intraspecific variation in birth season length with the majority of species reproducing for an expanded but determined period of more than two months. I further show that the most important factors influencing the degree of birth seasonality were mid-latitude, mean annual temperature, and precipitation in a species' geographical range, litter size and litters per year. Although less strongly, body mass was also correlated with birth season length. These results signify that environmental conditions of the natural habitats, as well as life history adaptations, determine birth seasonality in the order Lagomorpha.

\section{Characterization of birth seasonality in Lagomorpha}

Consistent with previous studies (e.g., Conaway et al. 1974; Smith 1978; Wood 1980; Gibb et al. 1985; Franken and Hik 2004; Tablado et al. 2009), lagomorphs show a large intraspecific variation in birth seasonality. This is especially true for Leporidae (rabbits, jackrabbits and hares) with wide geographical ranges (Schai-Braun and Hackländer 2016) and some very successful invasive species that have been introduced in numerous countries (Flux and Fullagar 1992; Montuire 2001; Chapman and Flux 2008). Since populations of several leporid species are known to adjust the length of their birthing season to their geographical location (Conaway et al. 1974; Bronson 1989; Tablado et al. 2009), large within-species variation might be a consequence of their extensive distribution. In species with a more limited geographic range, intraspecific variation in birth seasonality might occur because lagomorphs are known to reproduce very opportunistically with high year-to-year variability, depending on various factors such as weather and snow cover (Flux 1970; Franken and Hik 2004; Portales et al. 2004; Rödel et al. 2005; Morrison and Hik 2007), food availability (Flux 1970; Millar 1972; Smith 1978) and predation risk influencing population density (Wood 1980; Boonstra et al. 1998).

In contrast to leporids, most pikas (Ochotonidae) reproduce strictly seasonally. Many species of this family live at northern latitudes (Smith et al. 2018; Thapa et al. 2018), are high-altitude specialists (Smith 1974) and occur in limited distribution areas (Leach et al. 2015). These characteristics might explain their seasonal birthing pattern because the period of optimal environmental conditions for parturition and subsequent conception is short in northern alpine environments (Sparks and Menzel 2002), particularly for mammalian herbivores. The snow-free season is often shorter than two months and young must therefore be born late enough to avoid snow or low-quality food resources and early enough to allow growth and accumulation of body fat stores to survive the subsequent winter (O'Donoghue and Boutin 1995; Franken and Hik 2004). Thus, there is great selective pressure for early births, and short birthing periods for northern mountain-dwelling mammals such as many pika species (Smith 1978) (see below for the influence of latitude and altitude on birth seasonality).

\section{Factors associated with seasonal reproduction in Lagomorpha}

\section{Habitat characteristics: latitude, latitude range, altitude, temperature, precipitation and home range size}

Overall, this study shows that mid-latitude, mean annual temperature and precipitation of a species' habitat have a significant influence on reproductive seasonality in lagomorphs. Previous intraspecific studies in lagomorphs similarly confirmed a strong relationship between latitude and birth seasonality (Barkalow 1962; Conaway et al. 1974; Flux 1981; Gibb et al. 1985; Bronson 1989; Chapman and Flux 2008; Tablado et al. 2009). Birth windows became narrower with increasing latitude of the natural habitat, because spring starts later and winter starts earlier in the year, resulting in a decline of the length of the favourable season at higher latitudes (Sparks and Menzel 2002). Since reproduction requires significant energy investments, the optimal timing of parturition to avoid hostile conditions when offspring are unlikely to survive exerts a strong selective pressure for short birthing periods at high latitudes (Prendergast et al. 2002). Latitudinal range, however, had no influence on reproductive seasonality in lagomorphs. In comparable studies across rodent, primate and Carnivora species, I found that species with a wider latitudinal range had longer birth seasons (Heldstab et al. 2018, 2021; Heldstab 2021). However, the effect of latitudinal range was always much smaller than the effect of mid-latitude.

Another factor that is supposed to have similar effects as latitude on the reproductive strategy of lagomorphs is the mean altitude of species distribution. As for increasing latitude, the favourable season becomes shorter with increasing altitude (Mooney and Billings 1961; Sadleir 1969; Körner 
2007). I therefore expected that the birth season would be more pronounced for species living in high-altitudinal habitats. However, unlike previous studies in the Eastern cottontail (Sylvilagus floridanus) and Alpine mountain hares ( $L$. timidus varronis), which found an effect of altitude on the onset of reproduction (Conaway et al. 1974) or on litter size (Schai-Braun et al. 2017), I found no influence of altitude on reproductive seasonality across Lagomorpha.

As shown here and in previous single-species studies, habitats or years that were warmer (Hewson and Taylor 1975; Frylestam 1980; Myrberget 1983; Angerbjörn 1986; Tablado et al. 2009) and had a higher amount of precipitation (Vorhies and Taylor 1933; Bothma and Teer 1977; McKay and Verts 1978; Wilde 1979; Wood 1980) were associated with less seasonal reproduction. Low temperatures and low amounts of precipitation are associated with reduced food availability (e.g., reduced vegetation growth) (Boutin and Larsen 1993; Tablado et al. 2009) and with increased thermal stress (Gilbert et al. 1987; Rödel et al. 2004), resulting in poor body condition and a temporary cessation of breeding (Flux 1970; Andersson et al. 1981; Bell and Webb 1991; Rödel et al. 2005) consequently leading to a more seasonal reproduction.

\section{Life history traits: gestation length, litter size, litters per year, weaning age and age at sexual maturity}

Highly seasonal habitats provide shorter time windows of optimal conditions for breeding. Female mammals living in such environments are therefore expected to force maternal resources into a few large litters to maximise reproductive output while circumstances are favourable. Consistent with this prediction, I found that the majority of lagomorph species (with the possible exception of Ochotonidae, see below for the results of the four distinct ecotypes) with shorter birth seasons do have larger but fewer litters per year than species which a more expanded birthing pattern. A smaller comparative study across 22 lagomorph species also found that the number of litters decreases and the litter size augments with shorter breeding seasons (Swihart 1984). Studies using proxies for birth season length, such as latitude or temperature, similarly confirm the negative relationship between breeding season length and litter size intraspecifically in European hares (Lepus europaeus) (Hewson and Taylor 1975), Eastern cottontails (S. floridanus) (Conaway et al. 1974) and snowshoe hares (Lepus americanus) (Keith et al. 1966) and interspecifically in the genus Lepus (Flux 1981) and Sylvilagus (Lord 1960) and the family Leporidae (Virgos et al. 2006). Another study in European rabbits (Oryctolagus cuniculus) supports the present finding that the number of litters per year increased with the length of the breeding season (Tablado et al. 2009). In sum, there is ample evidence for Leporidae that litter size and the number of litters per year are adjusted according to their birth season length (see discussion of results for Ochotonidae below).

Other ways in which mammals gain selective advantages in seasonal habitats is by shortening gestation length and/ or accelerating foetal and neonatal growth to ensure that mating, birthing and raising offspring occur at a beneficial time of the year (Kiltie 1988; Zerbe et al. 2012; Heldstab et al. 2018, 2021; Heldstab 2021). Across eight New World rabbits, Chapman (1984) showed that species living at northern latitudes with shorter breeding seasons had a shorter gestation length. However, a higher degree of reproductive seasonality was not linked to a shorter gestation length in the present study, correcting for phylogenetic non-independence of taxa and covering a much higher number of species. In support, a study across 17 leporids was also not able to find a relationship between the variation of monthly average temperatures and gestation times (Virgos et al. 2006). Relative to other eutherian mammals, lagomorphs exhibit very short gestation periods (Swihart 1984; Wilson et al. 2016). Furthermore, females of many lagomorph species experience postpartum oestrus so that they can simultaneously suckle one litter while carrying another in the uterus with only a small increase in the duration of pregnancy (Millar 1973, 1974; Flux 1981; Keith 1981). In the genus Lepus, females are also known to superfetate, carrying a second fertilized ovum in their uterus during an already ongoing pregnancy (Flux 1967). These characteristics might be the reason for the absence of a correlation between gestation and birth season length in lagomorphs.

Concerning offspring growth in lagomorphs, Swihart (1984) found a correlation between the length of the breeding season and the age of first reproduction, but weaning age and age at sexual maturity had no influence on reproductive seasonality in the current study. These contrasting results suggest that the link between birth seasonality and ontogenetic development deserves future study in lagomorphs.

\section{Allometric variables: adult body mass and sexual size dimorphism}

Sexual size dimorphism had no influence on reproductive seasonality in lagomorphs. Another allometric variable, namely adult body mass, had no effect on birth seasonality measured in categories but correlated positively with birth season length measured in months. To my knowledge, there are no published studies investigating the relationship between breeding season length and either body mass or sexual size dimorphism in the order Lagomorpha. Analysing the breeding season length data of Swihart (1984) with a smaller sample size but a more precise measure of birth seasonality in days, the relationship between birth season length and both body mass (PGLS: $p=0.326, n=20, \lambda<0.001$, $\beta=24.195, \mathrm{SE}=23.953, t=1.010)$ as well as between birth 
season length and sexual size dimorphism (PGLS: $p=0.387$, $n=19, \lambda<0.001, \beta=-327.990, \mathrm{SE}=369.580, t=-0.887$ ) were not significant either. In Swihart's study, environmental conditions also had a stronger influence than body mass on several other reproductive traits. Davis and Roth (2008) found little evidence for a correlation between sexual size dimorphism and various fecundity-related traits in comparisons among cottontail rabbits.

\section{Factors associated with seasonal reproduction within the four distinct ecotypes}

As shown for the whole order of Lagomorpha, habitats that were warmer, had a higher amount of precipitation and were located at lower latitudes were also associated with less seasonal reproduction in hares and jackrabbits. These findings are consistent with single-species studies in this ecotype, e.g., in European hares (L. europaeus) (Hewson and Taylor 1975; Frylestam 1980), mountain hares (L. timidus) (Myrberget 1983; Angerbjörn 1986), antelope jackrabbits (Lepus alleni) (Vorhies and Taylor 1933), and black-tailed jackrabbits (Lepus californicus) (Vorhies and Taylor 1933).

Again consistent with the results across the whole Lagomorpha dataset, I also found that hares and jackrabbits with shorter birth seasons do have larger but fewer litters per year than species which a more expanded birthing pattern. Similarly, in rabbits, there was a tendency for species with a more seasonal reproduction to have fewer litters per year. Previous studies in hares and jackrabbits likewise confirm that litter size is inversely related to the duration of the reproductive season (Keith et al. 1966; Hewson and Taylor 1975; Flux 1981). Earlier published work, for instance in mountain hares (L. timidus) (Flux 1970; Kauhala et al. 2005), Eastern cottontails (S. floridanus) (Conaway et al. 1974) and European rabbits (O. cuniculus) (Tablado et al. 2009), supports the positive relationship between the number of litters per year and the length of the breeding season found in the present study within rabbits and within hares and jackrabbits.

Within the two ecotypes burrowing pikas and rock- and talus-dwelling pikas, none of the 13 factors had a significant influence on birth seasonality. However, the datasets comprising in most of the analyses less than 10 species are very small and problematic for phylogenetic comparative analyses (Münkemüller et al. 2012). It is therefore difficult to draw any firm conclusion from these analyses of the two ecotypes of pikas. As for many lagomorph species too, additional data for pikas are needed to solve the lack of knowledge concerning their reproductive seasonality and life history to make phylogenetic comparisons such as the present one possible.

\section{Comparison of reproductive seasonality in lagomorphs with other mammalian groups}

Similarly to rodents (Heldstab 2021) but unlike Carnivora (Heldstab et al. 2018), ruminants (Zerbe et al. 2012) and primates (Heldstab et al. 2021), many lagomorph species also show a large degree of intraspecific variation in birth season length. A possible explanation for this high withinspecies variation is that rodents and lagomorphs have a faster reproductive cycle than the other three orders (Case 1978; Eisenberg 1981; Swihart 1984) including a post-partum oestrus (Dewsbury et al. 1979) and superfetation in the genus Lepus (Flux 1967). This allows them to breed much more opportunistically and adjust birth season length according to predation risk (Wood 1980; Boonstra et al. 1998), weather (Bronson 1988; Franken and Hik 2004) or food abundance (Leslie et al. 1952; Millar 1972; Smith 1978; Wube et al. 2008). What is additionally expected to contribute to the high intraspecific variation in birth season length in rodents and lagomorphs is their occurrence across a much larger geographical range (Schai-Braun and Hackländer 2016; Wilson et al. 2016; Smith et al. 2018) than, for instance, primates, which are mostly confined to the tropics (Heldstab et al. 2021).

Mid-latitude of the species' geographical range, as well as mean annual temperature and precipitation had strong effects on reproductive seasonality in lagomorphs. Previous studies in Rodentia (Heldstab 2021), Ruminantia (Zerbe et al. 2012), Carnivora (Heldstab et al. 2018), Primates (Di Bitetti and Janson 2000; Janson and Verdolin 2005; Heldstab et al. 2021) and Macroscelidea (Neal 1995) also found that species living at higher latitudes have shorter breeding seasons.

In the present study across lagomorphs, habitats that were warmer and had a higher amount of precipitation were associated with longer seasonal reproduction. Comparative studies in rodents (Tkadlec 2000; Heldstab 2021) and primates (Heldstab et al. 2018) also showed a positive effect of temperature on the length of the breeding season. Mean annual precipitation in a species' habitat did not, however, translate into a less seasonal birthing pattern in these two orders. The strictly herbivorous diet of the large majority of lagomorphs might be responsible for the stronger influence of precipitation on their birth seasonality. Diets of rodents and primates are much more variable including also fruits, seeds, nuts, meat, or insects in significant proportions not observed in lagomorphs (Wilman et al. 2014). The broader diet range in these two orders likely makes food availability and ultimately reproductive seasonality less dependent on precipitation; in contrast, the lagomorph diet is mostly forbs, herbs and grasses. In addition, since many lagomorphs, in particular, pikas, live at high altitudes (Smith et al. 2018), snow might also elicit a stronger influence of precipitation on reproductive 
seasonality in comparison to the other two orders inhabiting mostly low-altitudinal habitats.

Solitary species with large home ranges do not often encounter potential mates (Llewellyn and Enders 1954; Greenwald 1956). Females of such species are therefore expected to have long oestrous periods to alleviate the uncertainty of finding a male (Larivière and Ferguson 2003). This should lead to less seasonal birthing patterns. A study in ursids supports this prediction, although the observed effect of home range size was small (Spady et al. 2007). The present study, a study with a larger sample of Carnivora species (Heldstab et al. 2018), as well as comparative studies in rodents (Heldstab 2021) and primates (Heldstab et al. 2021) were all unable to detect an influence of home range size on seasonal reproduction.

Contrasting what has been reported in primates (Heldstab et al. 2021), carnivores (Tökölyi et al. 2014; Heldstab et al. 2018) and ruminants (Zerbe et al. 2012; Tökölyi et al. 2014) but as found in rodents (Heldstab 2021), a higher degree of reproductive seasonality was not linked to a shorter gestation length in lagomorphs in the present study. I suggest two reasons for the difference between rodents and lagomorphs in comparison to the other mammalian orders: their small body size and their post-partum oestrus allowing them to gestate again immediately following the birth of the young. Large animals in seasonal environments need to reduce the length of their reproductive cycle to squeeze it into a single year, so that they do not lose out on the reproductive opportunity in the next year (Kiltie 1988). Small mammals such as rodents and lagomorphs exhibit extremely rapid foetal and neonatal growth rates and thus already have very short gestation periods (Swihart 1984; Wilson et al. 2016). The post-partum oestrus shortens the time between lactation and the next pregnancy, enabling rodents and lagomorphs to fit the complete reproductive cycle in an even shorter time window. Although lagomorphs do not adjust gestation length, they still seem to adapt life history to seasonal habitats with short favourable time windows, as seasonal Leporid species do have fewer but larger litters. Selection in highly seasonal environments has also favoured fewer litters in rodents (Heldstab 2021), bats (Tökölyi et al. 2014), elephant shrews (Neal 1995), and Eulipotyphla (Symonds 1999), larger litter sizes in primates (Heldstab et al. 2021), earlier weaning age in rodents (Heldstab 2021) and seals (Gentry and Kooyman 2014), and older age at sexual maturity in Eulipotyphla (Symonds 1999) and Rodentia (Heldstab 2021).

As found in primates (Heldstab et al. 2021) and carnivores (Heldstab et al. 2018), but unlike in ruminants (Zerbe et al. 2012) and rodents (Heldstab 2021), sexual size dimorphism in lagomorphs was not related to birth season length. Even in ruminants and rodents, sexual size dimorphism was also only marginally negatively associated with birth season length. The other allometric variable, body mass, also only had a small influence on lagomorph birth seasonality, as it was only correlated with birth season length measured in months but not in categories. Studies in primates (Plavcan et al. 2005; Heldstab et al. 2021), Carnivora (Heldstab et al. 2018), rodents (Heldstab 2021) and ruminants (Zerbe et al. 2012) demonstrate a similar weak impact of body mass on reproductive seasonality. In sum, habitat and life history characteristics seem to be much more important for lagomorph reproductive traits than allometric variables, as already suggested by Swihart (1984).

Supplementary Information The online version contains supplementary material available at https://doi.org/10.1007/s42991-021-00127-0.

Acknowledgements I thank Marcus Clauss for constructive comments and gratefully acknowledge the many people and institutions that have contributed data to my compilation. I am also thankful to the two reviewers for their very useful comments on the manuscript.

Funding Open Access funding provided by Universität Zürich.

Data availability All data generated or analysed during this study are included in this published article and its supplementary information files.

\section{Declarations}

Conflict of interest The author declares that she does not have any conflict of interest.

Open Access This article is licensed under a Creative Commons Attribution 4.0 International License, which permits use, sharing, adaptation, distribution and reproduction in any medium or format, as long as you give appropriate credit to the original author(s) and the source, provide a link to the Creative Commons licence, and indicate if changes were made. The images or other third party material in this article are included in the article's Creative Commons licence, unless indicated otherwise in a credit line to the material. If material is not included in the article's Creative Commons licence and your intended use is not permitted by statutory regulation or exceeds the permitted use, you will need to obtain permission directly from the copyright holder. To view a copy of this licence, visit http://creativecommons.org/licenses/by/4.0/.

\section{References}

Álvarez A, Ercoli MD, Prevosti FJ (2013) Locomotion in some small to medium-sized mammals: a geometric morphometric analysis of the penultimate lumbar vertebra, pelvis and hindlimbs. Zoology 116:356-371

Alves P, Rocha A (2003) Environmental factors have little influence on the reproductive activity of the Iberian hare (Lepus granatensis). Wildl Res 30:639-647

Alves PC, Gonçalves H, Santos M, Rocha A (2002) Reproductive biology of the Iberian hare, Lepus granatensis, in Portugal. Mamm Biol 67:358-371

Andersson M, Meurling P, Dahlback M, Jansson G, Borg B. (1981) Reproductive biology of the wild rabbit in southern Sweden, an area close to the northern limit of its distribution. In Myers K, 
MacInnes CD (eds) Proceedings of the World Lagomorph Conference. University of Guelph, Ontario, 175-181.

Angerbjörn A (1986) Reproduction of mountain hares (Lepus timidus) in relation to density and physical condition. J Zool 208:559-568

Angerbjorn A, Flux J (1995) Lepus timidus. Mammal Spec 495:1-11

Badingqiuying SAT, Senko J, Siladan MU (2016) Plateau pika Ochotona curzoniae poisoning campaign reduces carnivore abundance in southern Qinghai, China. Mammal Res 41:1-8

Bailey V (1936) The mammals and life zones of Oregon. US Government Printing Office, Washington D.C.

Barkalow FS (1962) Latitude related to reproduction in the cottontail rabbit. J Wildl Manag 26:32-37

Bednarz J (1977) The white-sided jackrabbit in New Mexico: Distribution, numbers, and biology in the grasslands of Hidalgo County. Unpublished report, New Mexico Department of Game and Fish, Santa Fe, NM, p 33p

Bell D, Webb N (1991) Effects of climate on reproduction in the European wild rabbit (Oryctolugus cuniculus). J Zool 224:639-648

Ben Saad M, Maurel D (2002) Long-day inhibition of reproduction and circadian photogonadosensitivity in Zembra Island wild rabbits (Oryctolagus cuniculus). Biol Reprod 66:415-420

Best TL (1996) Lepus californicus. Mammal Spec 530:1-10

Best TL, Henry TH (1993a) Lepus alleni. Mammal Spec 424:1-8

Best TL, Henry TH (1993b) Lepus callotis. Mammal Spec 442:1-6

Best TL, Henry TH (1994a) Lepus arcticus. Mammal Spec 457:1-9

Best TL, Henry TH (1994b) Lepus othus. Mammal Spec 458:1-5

Bogan M, Jones C (1975) Observations on Lepus callotis in New Mexico. Proc Biol Soc Wash 88:45-50

Boonstra R, Hik D, Singleton GR, Tinnikov A (1998) The impact of predator-induced stress on the snowshoe hare cycle. Ecol Monogr 68:371-394

Bothma JdP, Teer JG (1977) Reproduction and productivity in South Texas cottontail rabbits. Mammalia 41:253-282

Boutin S, Larsen KW (1993) Does food availability affect growth and survival of males and females differently in a promiscuous small mammal, Tamiasciurus hudsonicus? J Anim Ecol 62:364-370

Boyd I (1985) Effect of photoperiod and melatonin on testis development and regression in wild European rabbits (Oryctolagus cuniculus). Biol Reprod 33:21-29

Bronson F (1988) Mammalian reproductive strategies: genes, photoperiod and latitude. Reprod Nutr Dévelop 28:335-347

Bronson FH (1989) Mammalian reproductive biology. University of Chicago Press, Chicago

Cai G, Feng Z (1982) A systematic revision of the subspecies of highland hare (Lepus oiostolus) including two new subspecies. Acta Theriologica Sinica 2:167-182

Caravaggi A (2018) Lagomorpha life history. In: Vonk J, Shackelford TK (eds) Encyclopedia of animal cognition and behavior. Springer, Cambridge

Case TJ (1978) On the evolution and adaptive significance of postnatal growth rates in the terrestrial vertebrates. Q Rev Biol 53:243-282

Cervantes FA (1993) Lepus flavigularis. Mammal Spec 423:1-3

Cervantes FA, Lorenzo C, Hoffmann RS (1990) Romerolagus diazi. Mammal Spec 360:1-7

Cervantes FA, Lorenzo C, Vargas J, Holmes T (1992) Sylvilagus cunicularius. Mammal Spec 412:1-4

Chapman JA (1974) Sylvilagus bachmani. Mammal Spec 34:1-4

Chapman JA (1975) Sylvilagus nuttallii. Mammal Spec 56:1-3

Chapman JA (1984) Latitude and gestation period in New World rabbits (Leporidae: Sylvilagus and Romerolagus). Am Nat 124:442-445

Chapman JA, Flux JE (1990) Rabbits, hares and pikas: status survey and conservation action plan. IUCN, Gland, Switzerland

Chapman J, Flux J (2008) Introduction to the Lagomorpha. In: Alves P, Ferrand N, Hackländer K (eds) Lagomorph Biology: Evolution, Ecology, and Conservation. Springer, New York, pp 1-9
Chapman JA, Willner GR (1978) Sylvilagus audubonii. Mammal Spec 106:1-4

Chapman JA, Willner GR (1981) Sylvilagus palustris. Mammal Spec 153:1-3

Chapman JA, Hockman JG, Ojeda MMC (1980) Sylvilagus floridanus. Mammal Spec 136:1-8

Child M, Matthee C, Robinson T (2019) Pronolagus rupestris. The IUCN Red List of Threatened Species 2019: e.T41295A45190415. https://doi.org/10.2305/IUCN.UK.20191.RLTS.T41295A45190415.en

Conaway CH, Sadler KC, Hazelwood DH (1974) Geographic variation in litter size and onset of breeding in cottontails. J Wildl Manag $38: 473-481$

Corbet GB (1978) The mammals of the Palaearctic region: a taxonomic review. British Museum (Natural History), London

Córdova Izquierdo A, Ruiz Lang CG (1994) Biogeografía, ecología y etología de las liebres (Lepus callotis y Lepus californicus) en México. Cunicultura 19:213-216

Côté IM (2003) Knowledge of reproductive behavior contributes to conservation programs. In: Festa-Bianchet M, Apollonio M (eds) Animal behavior and wildlife conservation, 77-92. Island Press, Washington D.C

Cowan D, Bell D (1986) Leporid social behaviour and social organization. Mammal Rev 16:169-179

Cubas J, Martín-Esquivel JL, Nogales M, Irl SD, Hernández-Hernández R, López-Darias M, Marrero-Gómez M, del Arco MJ, González-Mancebo JM (2018) Contrasting effects of invasive rabbits on endemic plants driving vegetation change in a subtropical alpine insular environment. Biol Invasions 20:793-807

Davis CM, Roth VL (2008) The evolution of sexual size dimorphism in cottontail rabbits (Sylvilagus, Leporidae). Biol J Lin Soc 95:141-156

de Magalhães JP, Costa J (2009) AnAge: A database of vertebrate longevity records and their relation to other life-history traits. J Evol Biol 22:1770-1774

Delibes-Mateos M, Smith AT, Slobodchikoff CN, Swenson JE (2011) The paradox of keystone species persecuted as pests: a call for the conservation of abundant small mammals in their native range. Biol Cons 144:1335-1346

Dewsbury DA, Evans RL, Webster DG (1979) Pregnancy initiation in postpartum estrus in three species of muroid rodents. Horm Behav 13:1-8

Di Bitetti MS, Janson CH (2000) When will the stork arrive? Patterns of birth seasonality in neotropical primates. Am J Primatol 50:109-130

Durant P, Guevara MA (2000) Habitat of a Venezuelan lowland rabbit, Sylvilagus varynaensis (Lagomorpha: Leporidae). Revista de Ecologia Latinoamericana 7:01-10

Duthie A (1989) The ecology of the riverine rabbit Bunolagus monticularis. Master Thesis, University of Pretoria, South Africa. 79 pp

Eisenberg J (1981) The mammalian radiations: An analysis of trends in evolution, adaptation, and behaviour. University of Chicago Press, Chicago

Enari H, Sakamaki H (2012) Landscape-scale evaluation of habitat uses by sympatric mammals foraging for bark and buds in a heavy snowfall area of northern Japan. Acta Theriol 57:173-183

Farías V, Fuller TK, Cervantes FA, Lorenzo C (2006) Home range and social behavior of the endangered Tehuantepec jackrabbit (Lepus flavigularis) in Oaxaca, Mexico. J Mammal 87:748-756

Feldhamer GA, Thompson BC, Chapman JA (2003) Wild mammals of North America: biology, management, and conservation. Johns Hopkins University Press, Baltimore

Feng Z-J, Cai G-Q, Zheng C-L (1986) The mammals of Xizang. Science Beijing 1:441

Flux J (1967) Reproduction and body weights of the hare Lepus europaeus Pallas, in New Zealand. NZ J Sci 10:357-401 
Flux JE (1970) Life history of the mountain hare (Lepus timidus scoticus) in north-east Scotland. J Zool 161:75-123

Flux JEC. (1981) Reproductive strategies in the genus Lepus. In: Myers K, MacInnes CD (eds) Proceedings of the World Lagomorph Conference. University of Guelph, Ontario, 155-174

Flux JE, Fullagar P (1992) World distribution of the rabbit Oryctolagus cuniculus on islands. Mammal Rev 22:151-205

Flux JE, Jarvis JU (1970) Growth rates of two African hares, Lepus capensis. J Mammal 51:798-799

Forys EA (1995) Metapopulations of marsh rabbits: a population viability analysis of the Lower Keys marsh rabbit (Sylvilagus palustris hefneri). University of Florida, Gainesville

Franken RJ, Hik DS (2004) Interannual variation in timing of parturition and growth of collared pikas (Ochotona collaris) in the southwest Yukon. Integr Comp Biol 44:186-193

Freckleton RP, Harvey PH, Pagel M (2002) Phylogenetic analysis and comparative data: a test and review of evidence. Am Nat 160:712-726

Fritz SA, Bininda-Emonds ORP, Purvis A (2009) Geographical variation in predictors of mammalian extinction risk: big is bad, but only in the tropics. Ecol Lett 12:538-549

Frylestam B (1980) Reproduction in the European hare in southern Sweden. Ecography 3:74-80

Gentry RL, Kooyman GL (2014) Fur seals: Maternal strategies on land and at sea. Princeton University Press, Princeton

Ghose R (1978) Observations on the ecology and status of the hispid hare in Rajagarh forest, Darrang district, Assam, in 1975 and 1976. Bombay Natural History Soc J 75:206-209

Gibb J, White A, Ward C (1985) Population ecology of rabbits in the Wairarapa, New Zealand. N Z J Ecol 8:55-82

Gilbert N, Myers K, Cooke BD, Dunsmore J, Fullagar P, Gibb J, King D, Parer I, Wheeler S, Wood D (1987) Comparative dynamics of Australasian rabbit-populations. Wildl Res 14:491-503

Green JS, Flinders JT (1980) Brachylagus idahoensis. Mammal Spec 125:1-4

Greenwald GS (1956) The reproductive cycle of the field mouse, Microtus californicus. J Mammal 37:213-222

Gross JE, Stoddart LC, Wagner FH (1974) Demographic analysis of a northern Utah jackrabbit population. Wildl Monogr 40:3-68

Happold D (2013) Mammals of Africa. Vol. III Rodents, hares and rabbits. In: Kingdon J, Butynski TM, Happold D, Kalina J, Happold M, Hoffmann M (eds). Bloomsbury Publishing, London

Hayssen V, Van Tienhoven A, Van Tienhoven A (1993) Asdell's patterns of mammalian reproduction: A compendium of speciesspecific data. Cornell University Press, Ithaca, New York

Hearn BJ, Keith LB, Rongstad OJ (1987) Demography and ecology of the arctic hare (Lepus arcticus) in southwestern Newfoundland. Can J Zool 65:852-861

Heldstab SA (2021) Latitude, life history, and sexual size dimorphism correlate with reproductive seasonality in rodents. Mammal Rev $51: 256-271$

Heldstab SA, van Schaik CP, Isler K (2017) Getting fat or getting help? How female mammals cope with energetic constraints on reproduction. Front Zool 14:29

Heldstab SA, Müller DWH, Graber SM, Bingaman Lackey L, Rensch E, Hatt J-M, Zerbe P, Clauss M (2018) Geographical origin, delayed implantation and induced ovulation explain reproductive seasonality in the Carnivora. J Biol Rhythms 33:402-419

Heldstab SA, van Schaik CP, Müller DWH, Rensch E, Bingaman Lackey L, Zerbe P, Hatt J-M, Clauss M, Matsuda I (2021) Reproductive seasonality in primates: patterns, concepts and unsolved questions. Biol Rev 96:66-88

Hewson R, Taylor M (1975) Embryo counts and length of the breeding season in European hares in Scotland from 1960-1972. Acta Theriol 20:247-254
Holly T (2001) Mad world of the European hare. In: Macdonald DW (ed) The new encyclopedia of mammals. Oxford, Oxford University Press, pp 710-711

Innes DG, Millar JS (1995) Correlates of life-history variation in Clethrionomys and Microtus (Microtinae). Ecoscience 2:329-334

Isler K, van Schaik CP (2012) Allomaternal care, life history and brain size evolution in mammals. J Hum Evol 63:52-63

IUCN (2020) The IUCN Red List of threatened species. Version 20202. http://www.iucnredlist.org

Janson C, Verdolin J (2005) Seasonality of primate births in relation to climate. In: Brockman DK, van Schaik CP (eds) Seasonality in primates: Studies of living and extinct human and non-human primates, 307. Cambridge University Press, Cambridge

Jiang Y, Wang Z (1991) Social behavior of Ochotona cansus: Adaptation to the alpine environment. Acta Theriologica Sinica 11:23-40

Jones KE, Bielby J, Cardillo M, Fritz SA, O’Dell J, Orme CDL, Safi K, Sechrest W, Boakes EH, Carbone C et al (2009) PanTHERIA: a species-level database of life history, ecology, and geography of extant and recently extinct mammals. Ecology 90:2648-2648

Kauhala K, Helle P, Hiltunen M (2005) Population dynamics of mountain hare Lepus timidus populations in Finland. Wildl Biol 11:299-307

Keith LB. (1981) Population dynamics of hares. In Meyers K, MacInnes CD (eds) Proceedings of the World Lagomorph Conference, 395-440, University of Guelph, Ontario, Canada

Keith LB, Rongstad OJ, Meslow EC (1966) Regional differences in reproductive traits of the snowshoe hare. Can J Zool 44:953-961

Kiltie RA (1988) Gestation as a constraint on the evolution of seasonal breeding in mammals. In: Boyce MS (ed) Evolution of life histories of mammals. Theory and pattern, 257-289. Yale University Press, New Haven

Körner C (2007) The use of 'altitude' in ecological research. Trends Ecol Evol 22:569-574

Lancaster JB, Lee RB (1965) The annual reproductive cycle in monkeys and apes. In: De Vore I (ed) Primate behavior. Field studies of monkeys and apes, 486-513. Holt, Rinehart \& Winston, New York.

Larivière S, Ferguson SH (2003) Evolution of induced ovulation in North American carnivores. J Mammal 84:937-947

Leach K, Kelly R, Cameron A, Montgomery WI, Reid N (2015) Expertly validated models and phylogenetically-controlled analysis suggests responses to climate change are related to species traits in the order Lagomorpha. PLoS ONE 10:e0122267

Lechleitner RR (1959) Sex ratio, age classes and reproduction of the black-tailed jack rabbit. J Mammal 40:63-81

Leslie P, Venables UM, Venables L (1952) The fertility and population structure of the Brown Rat (Rattus norvegicus) in corn-ricks and some other habitats. Proc Zoolog Soc London 122:187-238

Lim BK (1987) Lepus townsendii. Mammal Spec 288:1-6

Lincoln G (1974) Reproduction and "March madness" in the brown hare, Lepus europaeus. J Zool 174:1-14

Lissovsky AA (2004) Ochotona turuchanensis. In: Romanov AA (ed) Vertebrate Fauna of the Putorana Plateau. Rosselkhozakademia, Moscow, pp 351-353

Litvaitis J, Lanier H (2019) Sylvilagus transitionalis. The IUCN Red List of Threatened Species 2019: e.T21212A45181534. https:// doi.org/10.2305/IUCN.UK.2019-2.RLTS.T21212A45181534.en.

Llewellyn LM, Enders RK (1954) Ovulation in the raccoon. J Mammal 35:440

Lockley RM (1976) The private life of the rabbit: An account of the life history and social behavior of the wild rabbit. Macmillan Publishing Co., New York

Lord RD (1960) Litter size and latitude in North American mammals. Am Midl Nat 64:488-499 
Lorenzo C, Brown D (2019) Lepus alleni. The IUCN Red List of Threatened Species 2019: e.T41272A45185265. https://doi.org/ 10.2305/IUCN.UK.2019-1.RLTS.T41272A45185265.en.

Lorenzo C, Cervantes FA, Barragán F, Vargas J (2006) New records of the endangered Tehuantepec jackrabbit (Lepus flavigularis) from Oaxaca, Mexico. Southwest Nat 51:116-119

Lorenzo C, Álvarez-Castañeda ST, Vázquez J (2011) Conservation status of the threatened, insular San Jose brush rabbit (Sylvilagus mansuetus). Western North American Naturalist 71:10-16

Lu X (2010) Demographic data on the woolly hare Lepus oiostolus near Lhasa, Tibet. Mammal Biol 75:572-576

Lumpkin S, Seidensticker J (2011) Rabbits: The animal answer guide. Johns Hopkins University Press, Baltimore, Maryland

MacDonald SO, Jones C (1987) Ochotona collaris. Mammal Spec 281:1-4

Maddison WP, Maddison DR. (2001) Mesquite: a modular system for evolutionary analysis, Available at http://mesquiteproject.org Accessed 15.11.2019

Martins EP, Hansen TF (1997) Phylogenies and the comparative method: A general approach to incorporating phylogenetic information into the analysis of interspecific data. Am Nat 149:646-667

Maser C, Mate BR, Franklin JF, CT, (1981) Natural history of Oregon coast mammals. Pacific Northwest Forest and Range Experiment Station, US Department of Agriculture, Forest Service, San Diego

McKay DO, Verts B (1978) Estimates of some attributes of a population of Nuttall's cottontails. J Wildl Manag 42:159-168

McNab BK (2006) The energetics of reproduction in endotherms and its implication for their conservation. Integr Comp Biol 46:1159-1168

Mengoni C (2011) Phylogeny and genetic diversity of Italian species of hares (genus Lepus). Università di Bologna, Bologna, $\mathrm{PhD}$

Millar JS (1972) Timing of breeding of pikas in southwestern Alberta. Can J Zool 50:665-669

Millar JS (1973) Evolution of litter-size in the pika, Ochotona princeps (Richardson). Evolution 27:134-143

Millar JS (1974) Success of reproduction in pikas, Ochotona princeps (Richardson). J Mammal 55:527-542

Molur S, Srinivasulu C, Srinivasulu B, Walker S, Nameer P, Ravikumar L (2005) Status of south Asian non-volant small mammals: conservation assessment and management plan (CAMP) workshop report. Zoo Outreach Organization/CBSG-South Asia, Coimbatore, India

Montuire S (2001) Lagomorpha (rabbits, hares and pikas). eLS. https:// doi.org/10.1038/npg.els.0001567.

Mooney HA, Billings W (1961) Comparative physiological ecology of arctic and alpine populations of Oxyria digyna. Ecol Monogr $31: 1-29$

Morrison SF, Hik DS (2007) Demographic analysis of a declining pika Ochotona collaris population: linking survival to broadscale climate patterns via spring snowmelt patterns. J Anim Ecol 76:899-907

Münkemüller T, Lavergne S, Bzeznik B, Dray S, Jombart T, Schiffers K, Thuiller W (2012) How to measure and test phylogenetic signal. Methods Ecol Evol 3:743-756

Myers P, Espinosa R, Parr C, Jones T, Hammond G, Dewey T (2006) The Animal Diversity Web. http://animaldiversity.ummz.umich. edu/

Myrberget S (1983) Early reproduction in 1983 of mountain hares on Tranoy study area in northern Norway. Suomen Riista 30:35

Naumov S, Shatalova S (1974) Species indices of reproduction in mammals and peculiarities of their geographic variation (Leporidae taken as an example). Zool Zhurnal 53:1856-1864

Neal B (1995) The ecology and reproduction of the short-snouted elephant-shrew, Elephantulus brachyrhynchus, in Zimbabwe with a review of the reproductive ecology of the genus Elephantulus. Mammal Rev 25:51-60

Nelson EW (1909) The rabbits of North America. US Government Printing Office

Newson J (1964) Reproduction and prenatal mortality of snowshoe hares on Manitoulin Island, Ontario. Can J Zool 42:987-1005

Nowak RM (1999) Walker's mammals of the world. Johns Hopkins University Press, Baltimore, Maryland

O’Donoghue M, Boutin S (1995) Does reproductive synchrony affect juvenile survival rates of northern mammals? Oikos 74:115-121

Oliver WL (1980) The pigmy hog: The biology and conservation of the pigmy hog, Sus (Porcula) salvanius, and the hispid hare. Caprolagus hispidus, Jersey Wildlife Preservation Trust

Orme CDL, Freckleton RP, Thomas GH, Petzoldt T, Fritz SA, Isaac NJ (2013) The caper package: comparative analysis of phylogenetics and evolution in R. R package version 0.5

Parker G (1977) Morphology, reproduction, diet, and behavior of the arctic hare (Lepus arcticus monstrabilis) on Axel Heiberg Island, Northwest Territories. Canadian Field Naturalist 91:8-18

Plavcan JM, van Schaik CP, McGraw WS (2005) Seasonality, social organization, and sexual dimorphism in primates. In: Brockman DK, van Schaik CP (eds) Seasonality in primates: Studies of living and extinct human and non-human primates. Cambridge University Press, Cambridge, pp 401-441

Portales GL, Hernández L, Cervantes FA, Laundré JW (2004) Reproduction of black-tailed jackrabbits (Lagomorpha: Lepus californicus) in relation to environmental factors in the Chihuahuan Desert, México. Southwest Nat 49:359-366

Portales-Betancourt GL, Hernández Laundré L, Laundré JW, Cervantes FA (2012) Reproducción y densidad de la liebre colanegra (Lepus californicus) en relación a factores ambientales, en la Reserva de la Biosfera Mapimí, Desierto Chihuahuense. Therya 3:172-183

Prakash I, Taneja G (1969) Reproduction biology of the Indian desert hare, Lepus nigricollis dayanus Blanford. Mammalia 33:102-117

Prendergast BJ, Nelson RJ, Zucker I (2002) Mammalian seasonal rhythms: behavior and neuroendocrine substrates. In: Pfaff D, Arnold A, Etgen A, Fahrbach S, Rubin R (eds) Hormones, brain and behavior. Academic Press, San Diego, California, pp 93-156

R Core Team. (2021) R: A language and environment for statistical computing. Version 4.0.4. R Foundation for Statistical Computing, Vienna

Retzer V (2007) Forage competition between livestock and Mongolian Pika (Ochotona pallasi) in Southern Mongolian mountain steppes. Basic Appl Ecol 8:147-157

Revin YU (1968) On the biology of the northern pika (Ochotona alpina Pallas) in the Olekmp-Charskoye upland region. Zool Zhurnal 47:1075-1082

Rioja T, Lorenzo C, Naranjo E, Scott L, Carrillo-Reyes A (2008) Polygynous mating behavior in the endangered Tehuantepec jackrabbit (Lepus flavigularis). Western North American Naturalist 68:343-349

Rioja T, Lorenzo C, Naranjo E, Scott L, Carrillo-Reyes A (2011) Breeding and parental care in the endangered Tehuantepec jackrabbit (Lepus flavigularis). Western North American Naturalist 71:56-66

Rödel H, Bora A, Kaetzke P, Khaschei M, Hutzelmeyer H, Von Holst D (2004) Over-winter survival in subadult European rabbits: weather effects, density dependence, and the impact of individual characteristics. Oecologia 140:566-576

Rödel HG, Bora A, Kaetzke P, Khaschei M, Hutzelmeyer HD, Zapka M, Von Holst D (2005) Timing of breeding and reproductive performance of female European rabbits in response to winter temperature and body mass. Can J Zool 83:935-942

Rogerson P (2001) Statistical methods for geography. Sage, London 
Rogowitz GL (1992) Reproduction of white-tailed jackrabbits on semiarid range. J Wildl Manag 56:676-684

Sadleir R (1969) The ecology of reproduction in wild and domestic mammals. Methuen \& Co, London

SAS Institute Inc. (1989-2016) JMP version 13.0. SAS Institute Inc Cary, North Carolina

Scarselli D, Mencarelli C, Gasperini M, Oliviero F, Petrini R, Riccetti A, Calamai S, Lari A, Segati M, Giannini F (2018) Diurnal and nocturnal home range of Italian hares (Lepus corsicanus) on Elba Island estimate by GPS technology. Poster Paper, XI Congresso Italiano di Teriologia, Firenze

Schai-Braun S, Hackländer K (2016) Family Leporidae. Hares and rabbits. In: Wilson D, Lacher T, Mittermeier R (eds) Handbook of the mammals of the world. Lagomorphs and rodents I., 62-148. Lynx Edicions, Barcelona

Schai-Braun SC, Gander J, Jenny H, Hackländer K (2017) Is reproductive strategy of Alpine mountain hares adapted to different elevations? Mamm Biol 85:55-59

Schai-Braun SC, Ruf T, Klansek E, Arnold W, Hackländer K (2020) Positive effects of set-asides on European hare (Lepus europaeus) populations: Leverets benefit from an enhanced survival rate. Biol Cons 244:108518

Schmidt W, Gourley M (1992) Black bear. Silvicultural approaches to animal damage management in Pacific Northwest forests. In: Black H (ed) United States Department of Agriculture Forest Service, Pacific Northwest Research Station General Technical Report-PNW-GTR-287. Portland, Oregon, USA, pp 309-331

Skalski JR (1976) Transferrin polymorphism in a population of Nuttall's cottontail in central Oregon. Master Thesis, Oregon State University. $56 \mathrm{pp}$

Skinner JD, Chimimba CT (2005) The mammals of the Southern African subregion. Cambridge University Press, Cambridge

Smith AT (1974) The distribution and dispersal of pikas: influences of behavior and climate. Ecology 55:1368-1376

Smith AT (1978) Comparative demography of pikas (Ochotona): effect of spatial and temporal age-specific mortality. Ecology 59:133-139

Smith A (1990) The pikas. In: Chapman J, Flux J (eds) Rabbits, hares and pikas: Status survey and conservation action plan. IUCN, Gland, Switzerland, pp 14-60

Smith AT (2018) Conservation of Lagomorphs. In: Smith AT, Johnston $\mathrm{CH}$, Alves PC, Hackländer K (eds) Lagomorphs: Pikas, rabbits, and hares of the world. Johns Hopkins University Press, Baltimore.

Smith A, Cook J (2016) Ochotona dauurica. The IUCN Red List of Threatened Species 2016: e.T41259A45182905. https://doi.org/ 10.2305/IUCN.UK.2016-3.RLTS.T41259A45182905.en.

Smith A, Johnston C (2016) Lepus yarkandensis. (errata version published in 2017) The IUCN Red List of Threatened Species 2016: e.T11796A115103994. https://doi.org/10.2305/IUCN.UK.20163.RLTS.T11796A45178274.en.

Smith A, Lissovsky A (2016) Ochotona macrotis. The IUCN Red List of Threatened Species 2016: https://doi.org/10.2305/IUCN.UK. 2016-3.RLTS.T41265A45183918.en.

Smith A, Liu S (2016) Ochotona thibetana. IUCN Red List of Threatened Species. IUCN. 2016: e.T41271A45185018. https://doi.org/ 10.2305/IUCN.UK.2016-3.RLTS.T41271A45185018.en

Smith AT, Weston ML (1990) Ochotona princeps. Mamm Spec 352:1-8

Smith AT, Xie Y, Hoffmann RS, Lunde D, MacKinnon J, Wilson DE, Wozencraft WC, Gemma F (2010) A guide to the mammals of China. Princeton University Press, Princeton

Smith AT, Johnston CH, Alves PC, Hackländer K (2018) Lagomorphs: Pikas, rabbits, and hares of the world. Johns Hopkins University Press, Baltimore
Smith AT, Wilson MC, Hogan BW (2019) Functional-trait ecology of the plateau pika Ochotona curzoniae in the Qinghai-Tibetan Plateau ecosystem. Integr Zool 14:87-103

Sokolov VE, Yu IE, Gruzdev VV (2009) Lagomorphs: Mammals of Russia and adjacent regions. Science Publishers, Enfield

Soto KH, Trites AW, Arias-Schreiber M (2004) The effects of prey availability on pup mortality and the timing of birth of South American sea lions (Otaria flavescens) in Peru. J Zool 264:419-428

Spady TJ, Lindburg DG, Durrant BS (2007) Evolution of reproductive seasonality in bears. Mammal Rev 37:21-53

Sparks TH, Menzel A (2002) Observed changes in seasons: an overview. Int J Climatol 22:1715-1725

Speakman JR (2008) The physiological costs of reproduction in small mammals. Philos Trans R Soc B 363:375-398

Stubbe M, Heidecke D, Stubbe A (1991) Populationsökologie von Kleinesäugerarten. Wissenschaftliche Beiträge der Universität Halle 34:231-265

Swihart RK (1984) Body size, breeding season length, and life history tactics of lagomorphs. Oikos 43:282-290

Symonds MR (1999) Life histories of the Insectivora: the role of phylogeny, metabolism and sex differences. J Zool 249:315-337

Symonds MR, Blomberg SP (2014) A primer on phylogenetic generalised least squares. In: Garamszegi L (ed) Modern phylogenetic comparative methods and their application in evolutionary biology. Springer, Berlin, pp 105-130

Tablado Z, Revilla E, Palomares F (2009) Breeding like rabbits: global patterns of variability and determinants of European wild rabbit reproduction. Ecography 32:310-320

Thapa S, Katuwal HB, Gurung R, Kusi N, Devkota B, Shrestha B, Suwal TL (2018) Pikas in Nepal. Small mammals conservation and research foundation, Kathmandu, Nepal, p 51

Tiemeier OW, Plenert ML (1964) A comparison of three methods for determining the age of black-tailed jackrabbits. J Mammal 45:409-416

Tkadlec E (2000) The effects of seasonality on variation in the length of breeding season in arvicoline rodents. Folia Zool 49:269-286

Tökölyi J, Schmidt J, Barta Z (2014) Climate and mammalian life histories. Biol J Lin Soc 111:719-736

Valdespino C (2007) Physiological constraints and latitudinal breeding season in the Canidae. Physiol Biochem Zool 80:580-591

Vargas Cuenca J, Cervantes FA (2005) Sylvilagus audubonii (Baird, 1858) Conejo del desierto. In: Ceballos G, Oliva G (eds) Los mamiferos silvestres de Mexico. Comision Nacional para el Conocimiento y Uso de la Biodiversidad, Fondo de Cultura Economica, Mexico, D. F, pp 838-839

Vaughan T, Ryan J, Czaplewski N (2013) Mammalogy. Jones \& Bartlett Learning, Burlington

Vázquez J, Chacón AJM, Hudson R, Rodríguez-Martínez L, MartínezGómez M (2007) Seasonal reproduction in Mexican cottontail rabbits Sylvilagus cunicularius in La Malinche National Park, central Mexico. Acta Theriol 52:361-369

Virgos E, Cabezas-Díaz S, Blanco-Aguiar JA (2006) Evolution of life history traits in Leporidae: a test of nest predation and seasonality hypotheses. Biol J Lin Soc 88:603-610

Vorhies CT, Taylor WP (1933) The life histories and ecology of jack rabbits, Lepus alleni and Lepus californicus ssp., in relation to grazing in Arizona. College of Agriculture. Agric Exp Stn Techn Bull 49:471-587

Wang Y, Luo Z, Feng Z (1985) Taxonomic revision of Yunnan hare, Lepus comus G. Allen with description of two new subspecies. Zool Res 6:101-109

Wells K, O'Hara RB, Cooke BD, Mutze GJ, Prowse TAA, Fordham DA (2016) Environmental effects and individual body condition drive seasonal fecundity of rabbits: identifying acute and lagged processes. Oecologia 181:853-864 
Wilde D (1981) Pygmy rabbit reproduction: possible modification by drought conditions. In: Myers K, MacInnes CD (eds) Proceedings of the World Lagomorph Conference. University of Guelph, Ontario, 559-571

Wilman H, Belmaker J, Simpson J, de la Rosa C, Rivadeneira MM, Jetz W (2014) EltonTraits 1.0: Species-level foraging attributes of the world's birds and mammals. Ecology 95:2027-2027

Wilson DE, Mittermeier RA (2009) Handbook of the mammals of the world. Lynx Edicions, Barcelona

Wilson DE, Mittermeier RA, Ruff S, Martínez-Vilalta A, Cavallini P (2016) Handbook of the mammals of the world: Lagomorphs and rodents I. Lynx Edicions, Barcelona

Wood D (1980) The demography of a rabbit population in an arid region of New South Wales Australia. J Anim Ecol 49:55-79

Wube T, Haim A, Fares F (2008) Reproductive response of xeric and mesic populations of the spiny mouse Acomys to photoperiod acclimation. J Arid Environ 72:440-447

Yamada F, Cervantes FA (2005) Pentalagus furnessi. Mammal Spec 782:1-5
Yamada F, Smith A (2016) Pentalagus furnessi. The IUCN Red List of Threatened Species 2016: e.T16559A45180151. https://doi.org/ 10.2305/IUCN.UK.2016-3.RLTS.T16559A45180151.en

Yamada F, Sugimura K, Abe S, Handa Y (2000) Present status and conservation of the endangered Amami rabbit Pentalagus furnessi. Tropics 10:87-92

Zerbe P, Clauss M, Codron D, Bingaman Lackey L, Rensch E, Streich JW, Hatt JM, Müller DW (2012) Reproductive seasonality in captive wild ruminants: implications for biogeographical adaptation, photoperiodic control, and life history. Biol Rev 87:965-990

Zimova M, Hackländer K, Good JM, Melo-Ferreira J, Alves PC, Mills LS (2018) Function and underlying mechanisms of seasonal colour moulting in mammals and birds: what keeps them changing in a warming world? Biol Rev 93:1478-1498

Publisher's Note Springer Nature remains neutral with regard to jurisdictional claims in published maps and institutional affiliations. 